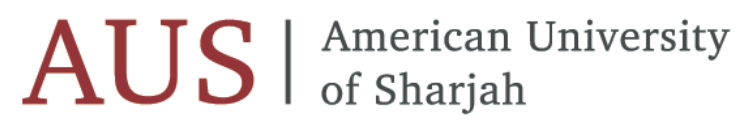

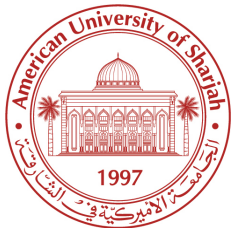

SCHOOL OF BUSINESS AND MANAGEMENT WORKING PAPER SERIES

SBMWPS: 08-06/2013

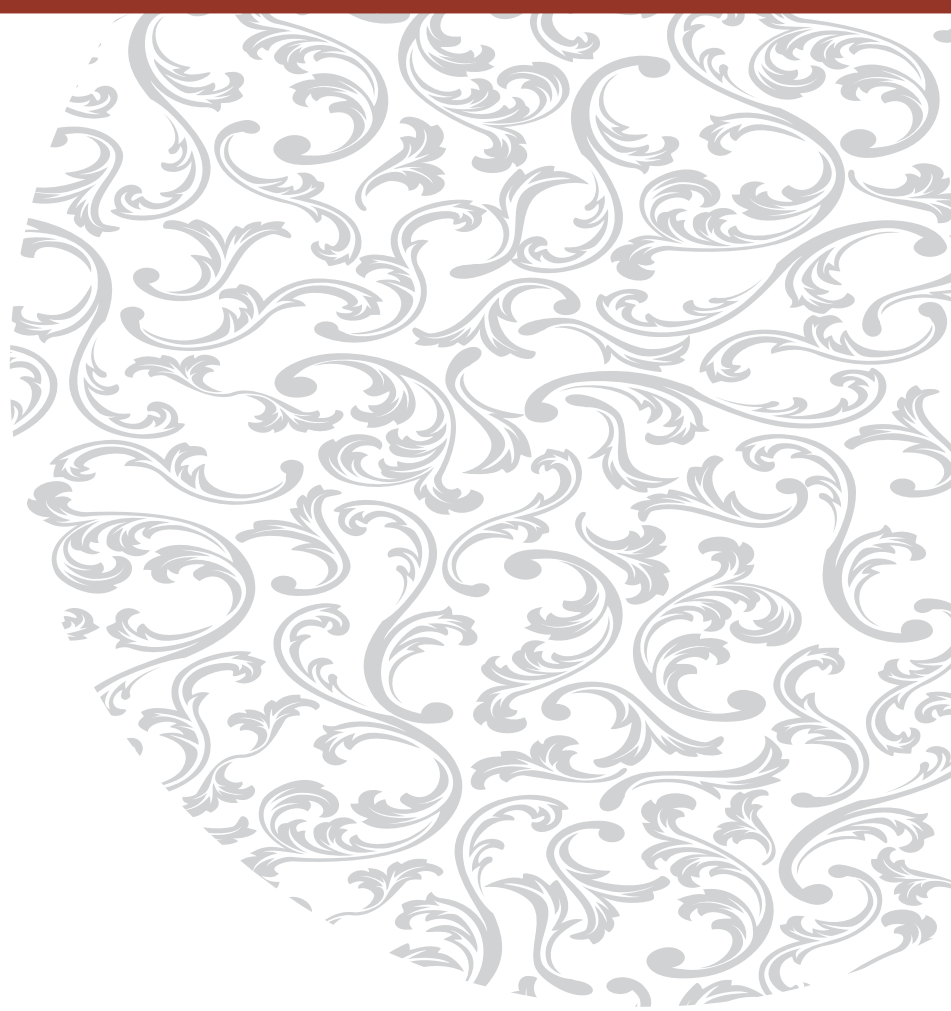

R\&D Productivity following

First-Time CIO Appointments

Ashraf Khallaf

Terrance R. Skantz 
Working Paper 08-06/2013

School of Business \& Management

Working Paper Series (SBM WPS)

\title{
R\&D Productivity following First-Time CIO Appointments
}

\author{
Ashraf Khallaf \\ American University of Sharjah
}

\section{Terrance R. Skantz}

University of Texas - Arlington

The views expressed in papers published in our series are those of the author(s) and do not necessarily represent those of any department at SBM, the SBM itself, the American University of Sharjah (AUS) and/or any of their affiliates. Additionally, all papers in the series are made available on an "as is" basis without warranties of any kind. We, that is, the relevant department at SBM, SBM, AUS and/or any of the affiliates, hereby expressly disclaim any warranties of any kind, whether expressed or implied, including without limitation, the warranties of noninfringement, merchantability, and fitness for a particular purpose. Furthermore, we offer no warranties, expressed or implied, regarding the accuracy, sufficiency or suitability of the material found in the published papers. The users have the sole responsibility for inspecting and testing all content to their satisfaction before using them. 


\title{
R\&D Productivity following First-Time CIO Appointments
}

\author{
Ashraf Khallaf
}

Terrance R. Skantz

Associate Professor of Accounting

American University of Sharjah

917-6-515-2457

akhallaf@aus.edu
Associate Professor of Accounting University of Texas - Arlington

817-272-3088

tskantz@uta.edu 


\title{
R\&D Productivity following First-Time CIO Appointments
}

\author{
Abstract \\ Prior studies find that firms announcing the appointment of a new chief information officer (CIO) are \\ rewarded by stock price increases, suggesting that the market expects new CIOs to add long-term value to the \\ firm. In this paper, we examine whether first-time CIO appointments result in improved R\&D productivity. \\ We focus on R\&D investments because an important role of IT management is to aid in discovery and \\ management of growth opportunities. Successful R\&D activities are designed to create the type of \\ knowledge-based, growth-critical assets (new or improved products, better distribution methods, etc.) that \\ effective IT management would be expected to assist. After controlling for industry performance, we find \\ that the productivity of R\&D improves significantly after the appointment of a new CIO. Further tests find \\ that R\&D productivity following the appointment of a first-time CIO is priced by the market as much or \\ more than productivity in the pre-appointment period, implying that the market perceives the productivity \\ improvements to persist. Our results for R\&D investments suggest that new CIOs improve the way IT is \\ managed and improve their firms' approach to knowledge management. One conclusion from this study is \\ that the IT productivity paradox may be resolvable by focusing on segments of performance that are most \\ directly impacted by improvement in IT management. We recommend avenue for further research.
}

Keywords: CIO appointments, $R \& D$ productivity. 


\section{R\&D Productivity following First-Time CIO Appointments}

\section{Introduction}

Research and development (R\&D) investment can generate new strategic options for business organizations (Bowman and Hurry 1993) and provide a source of competitive advantage (Lev and Sougiannis 1996). However, the empirical evidence with respect to R\&D investment and future performance is mixed. Some studies (Johnson 1967; Chan et al. 2001; Artes 2009) detect no relationship between R\&D investments and subsequent firm performance, while others (Lev et al. 2006; Chan et al. 2001; Sougiannis 1994; Shevlin 1991) find that R\&D investments increase a firm’s market value. Returns on R\&D investments exhibit substantial variation across firms (Aral and Weill 2007), even after controlling for organizational characteristics and industry level variation. The uncertainty surrounding R\&D investments, combined with the growing pressure to create and sustain competitive advantages, underlines the need of business organizations to effectively manage their R\&D activities (Bone and Saxon 2000).

In this paper, we examine the role of the Chief Information Officer (CIO) and information technology (IT) leadership to the success of R\&D activities. Both IT professionals and academics suggest that R\&D productivity may be influenced by the CIO and IT management practices. For example, Gartner EXP research director, Andy Rowsell-Jones, included technology development (R\&D, technology tracking, and prototyping) as one of four key responsibilities of CIOs. ${ }^{1}$ Similarly, when discussing the CIO’s role in enabling innovation in 2007, Rebecca Jacoby, Chief Information Officer for Cisco, points out that, “Leading

\footnotetext{
${ }^{1}$ http://www.gartner.com/press_releases/pr30sept2003a.html.
} 
organizations recognize that the strategic deployment of technology can be the critical enabler of virtually every business growth opportunity, especially those fueled by innovation.” ${ }^{2}$

Yayla and $\mathrm{Hu}$ (2008) provide empirical evidence that, in the view of boards of directors, CIOs play a critical role in enhancing R\&D productivity. In a study of CIO compensation over 1993 to 2005, the authors find a significant positive association between industry-level R\&D intensity and CIO compensation, suggesting that boards of directors perceive that a CIO's value to an organization is increasing with the importance of R\&D to a firm's success. Weill and Aral (2005) find that firms classified as IT savvy have more innovation from strategic IT initiatives (i.e., those designed to create growth through new products, new markets, etc.) ${ }^{3}$ In a review of the literature that examines the link between economic performance and information technology, Dedrick et al. (2003) point out that IT has the greatest impact on firm performance through its effect on coordination that "enables fundamental changes in business processes and organizational structures ....” (p.6).

In this paper, we examine the association between appointments to newly-created CIO positions and R\&D productivity. We predict that first-time CIO appointments will improve strategic IT management and, in turn, will result in an increase in the productivity of R\&D investments. We focus on first-time CIO appointments because a CIO appointment at the topmanagement level represents a commitment to strategic IT management which should help ensure that information technology is well-integrated with other functions inside the organization and effective in supporting an organization's strategy (Medcof 2008). We focus on R\&D productivity because strategic IT activities, in the sense of Weill and Aral (2005), should support the development and success of new products and markets. More broadly, in a knowledge-based

\footnotetext{
${ }^{2}$ http://www.cisco.com/en/US/solutions/collateral/ns340/ns857/ns860/CIO-Role-in-Enabling-Innovation.pdf.

${ }^{3}$ Weill and Aral (2005) classify IT activities and investments into four portfolios -- infrastructure, informational, transactional, and strategic. See section 3 below for details.
} 
economy, R\&D activities and supporting strategic IT initiatives are critical to obtaining and maintaining a competitive advantage. Finally, by focusing on R\&D productivity, and controlling for other factors that affect firm performance, we can at least partially avoid the effects of other events and circumstances that might confound the association between strategic IT initiatives and broader measures of firm performance.

To identify whether and how first-time CIO appointments are associated with R\&D productivity in the long-term, this study examines the change in $R \& D$ productivity in the three years following the CIO appointment. We control for firm size and industry performance because both factors could potentially affect R\&D productivity. We find that the productivity of R\&D activities increases following the first-time appointment of a CIO. Moreover, we find that capital markets price the productivity improvements as if they are relatively permanent. Our results illustrate how IT management can affect the success of R\&D activities.

To our knowledge, this is the first paper to study the effect of newly-appointed CIOs on the subsequent productivity of innovative activities. The lack of research is somewhat surprising given the perception that the $\mathrm{CIO}$ is important, if not critical, to the likelihood of garnering strategic value from IT. Thus, this paper fills a gap in the literature that is relevant to academics and practitioners. In summary, this study advances our understanding of the impact of strategic changes in IT management on R\&D productivity and also contributes to the literature that investigates the impact of R\&D on firm performance. While prior research focuses primarily on the valuation implications of R\&D investments, we argue that IT management is an important driver for productivity enhancement and we propose that the productivity of R\&D investments relies heavily on factors such as expertise and know-how of the IT management team. The 
appointment of a CIO is expected to provide firms with the knowledge and expertise needed to better manage $R \& D$ activities.

\section{Background}

\subsection{Relation to Prior Research}

Much of the prior research uses IT announcements as a focal point when measuring the return on IT investments, primarily due to the lack of public information about actual IT investments at the firm level. Two different methodologies are used to examine the return on IT investments, i.e., market returns surrounding IT investment announcements and long-term accounting performance following those announcements. While the market reaction to IT investment announcements provides insight into whether these investments are value-relevant to shareholders, accounting return measures in the years following IT investment announcements determine whether these investments are, in fact, long term value-adding.

As exceptions to the above line of research, Kobelsky et al. (2008) and Aral and Weill (2007) use budgetary data for IT investments to measure whether these investments pay off. Kobelsky et al. (2008) use IT budget data to examine the determinants and consequences of firms’ IT budgets. However, IT budget data is only available for Information Week 500 firms (IW 500) and is available only for the period from 1991 to 1997. Since the IW 500 focuses on large firms that are recognized for their innovative use of IT resources, the data is unlikely to be representative of all public firms. Aral and Weill (2007) survey senior IT executives of 147 U.S firms to solicit input from participants on the components of IT investments during 1999-2002. The data are not available for larger sample firms, and it is vulnerable to respondents' subjective assessments and subject to single respondent bias. 
In summary, previous research that has examined the payoff from IT investments has relied on public announcement of IT investments or privately gathered surveys on IT spending. The lack of public data about IT investments for a large sample of firms has been the primary limiting factor for research in this area, and may be one reason for the mixed results found in studies of returns to IT investments. Furthermore, research that measures the impact of IT investments on firm performance, in general, equates potentially heterogeneous IT investments by focusing on the aggregate IT investments and not differentiating among the different types of IT activities (Bhatt and Grover 2005 ; Wade and Hulland 2004). By not distinguishing between different types of IT activities, Carr (2003) comes to a conclusion that firms cannot gain a competitive advantage from their investments in IT, and he encourages managers to avoid or take a defensive posture as regard to the high cost of IT leadership.

Our goal in this paper is to sharpen the theoretical perspective of IT resources by unpacking one major type of IT investment (i.e., strategic IT investment) and measure its association with on aspect of firm performance following the appointment of CIO. Of the four types of IT investments (Weill and Aral 2005), we choose to focus on the strategic IT investment because strategic IT contributes directly to product innovation that influences a firm's ability to sustain a competitive advantage (Bhatt and Grover 2005; Artz et al. 2003; Caves and Ghemawat 1992). Strategic IT investments evolve over time and are the product of knowledge and expertise that is not easily duplicated by competitors. Yet, empirical evidence about the effect of IT expertise on the productivity of strategic IT investments is limited. We view a first-time CIO appointment as a strategic change in IT management that should enhance R\&D productivity 


\subsection{Market Reaction to CIO Appointments}

CIOs are expected to add value to business organizations by facilitating interactions with other chief executive officers and enhancing the strategic role of IT (Armstrong and Sambamurthy 1999; Feeney et al. 1992). Firms appoint a CIO with the expectation that the CIO will lead the company to achieve a competitive advantage through better management of IT implementation ${ }^{4}$ and by improving strategic decisions at the firm level. Prior research finds that the appointment of a new CIO is associated with an increase in the market value of the appointing firm (on average) around the announcement date. Chatterjee et al. (2001) find that the market’s reacts favorably to announcements of newly-created CIO positions over 1987-1998 and that the reaction is more pronounced in firms that are newly integrating IT into their business strategy. In related research, Guan et al. (2006) reexamine the sample used in Chatterjee et al. (2001) and find significant 'pre-announcement' positive abnormal returns for those firms tracked by financial analysts. ${ }^{5}$ This suggests that the positive market reaction may have been larger than originally reported by Chatterjee et al. (2001).

In a study of CIO appointments using an expanded sample from the 1987-2002 period, Khallaf and Skantz (2007) compare the market reaction to (a) announcements that create and fill a new CIO position and (b) announcements that fill an existing position with a new hire. The mean abnormal returns for both sets of announcements are significantly positive and the two are not significantly different from one another. The market reaction is more pronounced when the new CIO is hired from an IT leader firm and when the appointment is early for its industry. Their

\footnotetext{
${ }^{4}$ Effective IT implementation capability enables firms to (1) incorporate IT strategy into each department's planning process, (2) integrate reliable and cost-effective applications that enhance the ability to win in the new competitive environment, and (3) design future IT strategies that builds on innovation of new products or services features faster than competitors (Bharadwaj 2000).

${ }^{5}$ One can speculate about how the information becomes available to the market prior to formal announcement. It is possible that management leaks information to analysts who in turn share that information with their clients. Alternatively, analyst coverage may be a surrogate for the private information search activity that is able to detect the pending announcement through superior information processing skills.
} 
results are consistent with earlier studies that reveal a positive market reaction to announcements appointing an expert at the top management level and studies that find that managerial labor markets and capital markets are jointly integrated (DeFond et al. 2005; Davidson et al. 2004; Ang et al. 2003).

These short-window market reaction tests suggest that capital market participants believe that new CIO positions signal favorable changes in IT strategy and that high quality appointees enhance the probability of effectively implementing new or existing strategies. However, the stock returns around announcements of CIO appointments provide no direct evidence on whether the market reaction is an accurate indication of firms' long-term performance following CIO appointments. In a companion paper, Khallaf and Skantz (2010) examine long-term accounting performance subsequent to the CIO announcements. Their results suggest that the decision to create and fill a new CIO position erases prior poor performance and that first movers enjoy higher financial performance following CIO appointments than later appointing firms.

\subsection{R\&D, IT Investments and Firm Performance}

Studies of the impact of R\&D and IT investments on firm performance are very similar in terms of direction and focus. Some studies show mixed results (Johnson 1967; Chan et al. 2001), while others detect a positive relationship between each type of investment and firm performance or firm value (Kobelsky et al. 2008; Lev and Sougiannis 1996). Kobelsky et al. (2008) use IT budget data and find a positive relationship between IT investments and subsequent firm profitability. Similarly, Lev and Sougiannis (1996) detect a positive relationship between R\&D expenditures and subsequent accounting returns.

In combining of the above lines of research, Shin (1997) examines the relationship between firm output (measured as sales plus changes in inventory) and other specific 
expenditures that include IT and R\&D investments. Output is positively related to both types of investments. In parallel findings, both R\&D and IT investment announcements generate positive abnormal market returns. Oh et al. (2006) and Dehning et al. (2003) observe positive market reactions to IT investments and their findings indicate that contextual variables including firm growth, uncertainty and the strategic role of IT are significantly related to abnormal stock returns. In the same vein, Eberhart et al. (2004) and Chan et al. (2001) provide evidence that firms characterized by high R\&D intensity experience significant positive abnormal stock returns.

Most firms have access to similar IT resources but are not equally effective in utilizing information technology for strategic purposes (Barua et al. 1995; Barua et al. 2008). Achieving returns above the industry average requires matching a firm's investment in IT-related activities with management capabilities (Weill and Aral 2005). Decisions on strategic IT activities require thorough understanding about organizational processes and competitive situation.

It would be quite surprising if firm's investments (whether in IT, R\&D, manufacturing assets, etc.) were not, on average, positively associated with firm performance. Evidence that R\&D and IT investments generate returns that beat industry averages is consistent with project evaluation using discounted cash flow criteria, wherein proposals are accepted only if they promise returns in excess of the opportunity cost of capital (i.e., positive net present value projects). This paper tests whether returns to $R \& D$ investments are higher after appointing a new CIO than before. Under the assumption that R\&D investments are, on average, positive net present value projects, this paper effectively tests whether the excess returns associated with R\&D investments increase after appointing CIOs for the first time. 


\section{Research Hypotheses}

Weill and Ross (2004) study IT governance in over 250 organizations in 23 countries and find that top-performers manage IT activities differently than their weaker competitors. The authors conclude that effective IT management allows organizations to achieve superior results on their IT investments. Bharadwaj (2000) argues that effective IT management enables a firm to incorporate IT strategy into each department's planning process and to design future IT strategies that build on innovation faster than competitors.

Of the four types of IT activities (infrastructure, transactional, informational and strategic as discussed below), strategic activities provide applications associated with product innovative (Aral and Weill 2007). Since R\&D activities are designed to create knowledge that leads to new products, new markets, new technologies, or other sources of competitive advantage, we use R\&D expenditures as a proxy for investment in options on knowledge-based assets. This view is consistent with the primary objective of R\&D activities, i.e., acquiring new knowledge that fosters the development of new products, services or processes (Tsang et al. 2008).

Prior research finds that firms employing IT as a strategy for competitive advantage outperform their competitors (Bharadwaj 2000; Dehning and Stratopoulos 2002) and that organizational capabilities moderate the relationship between investment in IT activities and firm performance (Brynjolfsson and Yang 1997; Bharadwaj 2000). Tanriverdi (2005) surveys senior IT executives of 250 Fortune 1000 firms and finds a significant indirect impact on firm performance through the moderation of knowledge capability. Similarly, Dehning et al. (2003) argue that the lack of a significant association between IT investments and firm performance could be attributed to the poor management of information and technology. 
Organizations are expected to align their investments in strategic IT activities with their technological capabilities and their IT management practices (newly-created CIO positions). We rely on Aral and Weill's (2007) description of IT investments to develop a theoretical model of factors influencing the productivity of R\&D. As shown in Figure 1, knowledge management affects the productivity of R\&D investments. We explain the theory behind figure 1 in the following sections as we develop our hypotheses. First, we describe the four types of IT investments and their objectives. Then, we discuss the impact of knowledge management on R\&D productivity.

\subsection{Types of IT Investments}

Aral and Weill (2007) classify IT investments into four distinct types of activities -infrastructure, transactional, informational and strategic. Each of these activities achieves different management objectives and impact different aspect of firm performance. Using survey instruments, Aral and Weill (2007) asked senior IT executives of 147 U.S firms to classify their total IT budget into the four IT activities. The authors find that while aggregate IT investment is not associated with performance, investment in specific IT activities yield different payoffs consistent with their underlying purpose.

IT activities at the infrastructure, transactional and informational levels supply the foundation for IT service that enables a firm to automate processes and provide information needed to communicate with other parties inside and outside the organization. Strategic IT activities contribute directly to product innovation by providing new services or enabling new products. The first three dimensions of IT activities are structural necessities for business organizations rather than a means of competitive advantage; in other words, benefits expected from these activities are largely played out among competitors. There is very little difference 
among well-established firms with respect to the quality of IT infrastructure because of " the increasingly open standards, modular development approaches, and lower cost with respect to transaction platforms, enterprise resource planning (ERP), TCP/IP-based communication and packaged software” (Bhatt and Grover 2005, 270). IT infrastructure has been described in prior research as an effective source of value and not a source of competitive advantage (Bharadwaj 2000; Broadbent et al. 1999).

Investments in the basic IT activities (infrastructure, transactional, and informational) are necessary to support IT service in response to competitors' investment in similar IT activities (Barua et al. 1995). Bhatt and Grover (2005) argue that when established firms capitalize on similar sets of resources, those resources will be available either in the marketplace or become easy to duplicate by competitors. The authors find no significant relationship between higher quality IT infrastructure and competitive advantage, supporting the conjecture that investment in IT infrastructure maintains parity rather than contributes to sustainable superior performance.

Strategic IT activities, as opposed to more fundamental IT activities, are the instruments needed to implement business strategies and improve a firm's competitive position in the market place (Aral and Weill 2007; Hallikainen et al. 2002). To improve its competitive position, a firm invests in IT activities beyond those devoted for building the infrastructure for IT services. Aral and Weill (2007) argue that strategic IT activities are likely to provide a sustainable competitive advantage by supporting entry into new markets, and developing new products, services or business processes. From an economic perspective, Caves and Ghemawat (1992) examine the factors that lead to intra-industry profit differentials and find that differentiation-related strategies (which include R\&D) are indicative of innovation in the product market and, accordingly, play a more essential role than cost-related strategies. 


\subsection{Knowledge Management and R\&D Productivity}

Economic theory argues that knowledge is an essential driver of firm value. Machlup (1962) documents the shift in US economy from industrial to knowledge-based, and argues that while the success in an industrial economy depends on tangible inputs, the success in our modern economy relies on investments in assets such as expertise and know-how. Such shifts in market demand have been driven in large part by IT management (Autor et al. 1998).

DeFond et al. (2009) study the stock market reaction and future performance of companies that are to receive a "Most Admired Knowledge Enterprise" (MAKE) award. MAKE winners are selected by panels of knowledge-management experts that include a CIO as one of the key members. The panels identify firms that utilize knowledge management to create firm value. The MAKE award is a proxy for superior knowledge-management capabilities. The authors find that award winners experience positive abnormal returns around the award announcement and achieve superior operating performance relative to their peers following the MAKE awards. These findings are consistent with economic theory that argues that knowledge is a fundamental driver of firm value. In the strategic management literature, knowledgemanagement capability is difficult to imitate and therefore can provide the firm with a long-term competitive advantage (Nonaka 1991). Barriers to the transfer and replication of knowledge lend credence to its strategic importance (Alavi and Leidner 1999).

According to this perspective, firms create value through knowledge management by combining and applying resources to produce new products or embrace new technologies. This perspective extends the resources-based view of the firm (Alavi and Leidner 1999). In particular, knowledge management is central to product and process innovation (Eral 2001). Because knowledge management is critical to R\&D productivity, we predict that an effective strategic IT 
backbone will readily enhance returns from R\&D activities. Using data drawn from a broad global sample of major chemicals firms, Roberts and Bellotti (2002) demonstrate that firms adopting specific management for their technology strategies enjoy higher overall R\&D productivity.

Berson and Linton (2005) argue that R\&D success depends mainly on effective leadership. The interaction between IT business strategy and innovation suggests that R\&D leadership provides sustained profit differentials across firms (Lev et al. 2006). Uttal et al. (1992) discuss three levels of technology leadership for the CIO -- functional, strategic and supra functional. While the purpose of functional leadership is to ensure the effective operation of $R \& D$, the strategic leadership aims to ensure that $R \& D$ and corporate strategies are aligned, and supra functional emphasizes the process of developing a strategy in all areas of operations and not just for the technology function. The strategic importance of technology for a firm determines the degree of the $\mathrm{CIO}$ involvement in managing R\&D activities. ${ }^{6}$

Since the CIO is responsible for shaping the flow of information, linking technology strategy with overall firm strategy, and molding the strategic management of technology processes, we expect a positive correlation between $R \& D$ productivity and the appointment of a CIO. If newly-appointed CIOs enhance the strategic value of IT, we should observe higher returns to investments in knowledge-based activities following a CIO appointment. We argue that improvements in strategic IT management should have the greatest productivity-effect on knowledge-based activities. Using R\&D expenditures as a proxy for investments in knowledgebased assets, we predict that the effects of improvements in strategic IT management will readily reveal itself through improvements in $\mathrm{R} \& \mathrm{D}$ productivity.

\footnotetext{
${ }^{6}$ While Uttal et al (1992) use the phrase "CTO," a 2001 survey ("State of the CIO") found that "Only 65 out of 500 (13 percent) heads of IT use the CTO title.” Thus we use the term CIO to be consistent with common usage.
} 
An appointment to a newly-created CIO position suggests a change in the strategic importance of IT management to the appointing firm. A strategic shift with respect to IT management is less likely when a firm is making a second or later appointment to an existing position. Chatterjee et al. (2001) argue that IT leadership differentiates firms' IT capabilities. The authors find that the market rewards firms when they create a CIO position for the first time.

If new CIOs represent an increased commitment to strategic IT initiatives, R\&D investments (i.e., call options on new products and processes) are more likely to mature into valuable claims to new products and processes (i.e., finish in the money). Consequently, firms that appoint a CIO to a new position are expected to experience an improvement in their $\mathrm{R} \& \mathrm{D}$ productivity relative to their own pre-appointment performance. Thus, we predict that R\&D productivity will increase following first-time $\mathrm{CIO}$ appointments. Hence, the first hypothesis is:

H1: R\&D productivity will increase following the appointment of a CIO to a new position.

\subsection{The Market’s Valuation of R\&D Productivity}

In addition to examining changes in $R \& D$ productivity following the creation of a new CIO position, we examine the market's interpretation of those productivity changes. The reason for this latter analysis is to examine whether improvements in accounting performance translate into increases in market value or whether changes in accounting performance are dismissed by the market as temporary. If share price reflects improvements in R\&D productivity, we can conclude more confidently that the market views the changes in performance as a valid indicator that newly-appointed CIOs provide a sustainable competitive advantage. Because we view the appointment of a first CIO as a strategic repositioning of IT, we predict that the market will value 
firm performance and R\&D investments following the appointment of a first $\mathrm{CIO}$ as much as or more firm performance before the appointment of the new CIO. Our second hypothesis is:

H2: The market will value firm performance and R\&D investments following the appointment of a CIO to a new position as much as or more than before the appointment.

\section{Sample Selection and Research Methodology}

\subsection{Sample Selection}

CIO appointing firms are identified through a Lexis-Nexis search of announcements to fill a new CIO position during the period 1987-2008. ${ }^{7}$ Information concerning firm performance and their financial statement information is obtained from Standard and Poor's Compustat database. To examine the change in R\&D productivity following first-time CIO appointments, we gather financial data for each firm for seven years $t=-3$ to $t=+3$, where $t=0$ is the announcement year. Thus, the financial data are terminated with fiscal year 2011. Of all CIO appointments, there are 177 first-time CIO appointments announcements with financial statement data at the announcement year. The sample is reduced to 118 firms by the requirement that data are available in the last two years of the pre-announcement window $(\mathrm{t}=-2,-1)$ and also the first two years of the post-announcement window $(t=+1,+2)$. The reduction in sample size reflects the relative large number of $\mathrm{CIO}$ appointments during the turbulent market period of the late 1990s and early 2000s - a time period during which the number of U.S. publicly-traded firms declined. ${ }^{8}$

The accounting performance of each sample firm is measured relative to the industry median performance. Measuring changes in firm performance following the CIO appointment

\footnotetext{
${ }^{7}$ The initial CIO sample is the same one used in Khallaf and Skantz (2007). Sample details are available upon request.

${ }^{8}$ The number firms covered by Compustat went from approximately 7720 in 1986 to a peak of 10470 in 1996 to 8147 in 2005.
} 
relative to its industry peers can help identify whether a firm has achieved a competitive advantage and also isolates the potential effect of unidentified exogenous variables. The economic performance of a firm's industry serves as a performance benchmark and provides a vital tool for removing the confounding effects of systematic, external factors that affect firm performance.

We use the global industry classification standard (GICS) to define industry subgroups. Industry classifications created using GICS explain a considerably greater proportion of the cross-sectional variations in firm level return measures than industry classifications produced on the basis of SIC, NAICS, or Fama-French (Bhojraj et al. 2003). The GICS system classifies firms according to their major business activities and forms homogeneous sub-industries that have similar operating characteristics (Bhojraj et al. 2003). We use the full 8-digit GIC code, which corresponds to 123 different industry subgroups. A firm must have at least 10 firms in its industry in any year to be retained in our tests. ${ }^{9}$

\subsection{Performance Measures}

One advantage of using accounting-based returns to assess the impact of changes in IT management on firm performance is that accounting returns are largely independent of the dramatic market shifts occurring during our sample period. In particular, the market bubble of the late 1990's and subsequent correction in late 2000 and early 2001 are unlikely to be related to firm-specific choices.

Accounting-based performance measures have been widely used to examine the impact of IT investments on firm performance (Santhanam and Hartono 2003; Bharadwaj 2000). Various profitability measures are possible, including return on assets (ROA), return on book equity (ROE), and return on market capitalization. We use ROA as a performance measure

\footnotetext{
${ }^{9}$ This reduced the sample by only two CIO-appointing firms.
} 
because that measure is important in financial analysis and in prior IT research. Studies analyzing long-term performance find a positive link between investment in IT and ROA (e.g., Santhanam and Hartono 2003; Bharadwaj 2000). Since the benefits of appointing a new CIO include improved firm operating efficiency and profitability, we purposely focus on ROA as it incorporates both factors. Our measure of return on assets is based on earnings before taxes, interest, and depreciation (Compustat's OIBDP) rather than net income. ${ }^{10}$ We use an operating return measure of firm performance because operating returns are unaffected by financing choices, tax management practices, and depreciation policies. We do not believe that financing decisions, tax management, or deprecation policy is likely to be affected by strategic IT decisions.

\subsection{Regression models}

\subsubsection{Hypothesis 1}

Our regression models include mean industry performance as an independent variable to control for systematic factors that affect all firms in an industry and that are unrelated to CIO appointments. H1 predicts that the productivity of knowledge-based assets (R\&D investments) and the contribution of those assets to firm performance will improve following the CIO appointment. The new $\mathrm{CIO}$ is predicted to be important in reshaping knowledge management which in turn should increase the productivity of investments in knowledge-based assets. Accordingly, we structure regression models to examine whether a specific slice of firm performance is improved after bringing a new $\mathrm{CIO}$ into the top management group. The test of H1 uses R\&D spending as a proxy for investment in knowledge-based assets. The regression model used to test $\mathrm{H} 1$ is as follows:

\footnotetext{
${ }^{10}$ Bold, upper case characters are used to refer to Compustat variable acronyms.
} 


$$
\begin{aligned}
\mathrm{ROA}_{\mathrm{it}} & =\alpha+\beta_{1} \mathrm{mdROA}_{\mathrm{it}}+\beta_{2} \log \mathrm{MV}_{\mathrm{it}}+\beta_{3} \mathrm{POST}_{\mathrm{it}}+\beta_{4} \mathrm{RD}_{\mathrm{it}}+\beta_{5} \mathrm{POST}_{\mathrm{it}} * \mathrm{RD}_{\mathrm{it}}+ \\
\mathrm{FE}_{\mathrm{t}} & +\varepsilon_{\mathrm{it}}
\end{aligned}
$$

ROA (return on assets) is firm performance in year t, found as income before interest, taxes and depreciation (Compustat item, OIBDP) divided by average total assets (AT). mdROA is the industry median ROA over the firm's fiscal year. LogMV is the natural log of firm market value, where market value is measured as fiscal year-end stock price (PRCC_F) multiplied by the number of common shares outstanding (CSHO) at year end. The market value of a firm is included in the model to control for the effect of size on ROA. POST is a dummy variable equal to 1 for fiscal years $t=1, t=2$ and $t=3$ following the CIO appointment, and 0 for years $t=-3, t=-2$, and $t=-1$. The year of the CIO appointment is omitted from regression models. POST is included as an independent variable to capture the change in firm performance following the CIO appointment. RD is research and development expenditure (XRD) scaled by average total assets. We scale by average total assets to be consistent with the scaling used to measure firm performance (ROA). The coefficient for POST*RD tests whether IT management capability moderates the relationship between investments in knowledge-based assets and firm performance. FE represents indicator variables to capture year fixed effects. We include year fixed effects to isolate changes in the level of ROA over time. Year fixed effects are potentially important because our sample period includes a bubble period when corporate earnings and stock prices are unusually high and a later recession period when the opposite is true. $\mathrm{H} 1$ predicts that $\beta_{5}>0$.

In robustness tests, we use the sum of advertising (XAD) and $R \& D$ expenditures (XRD) as a proxy for investment in knowledge-based assets. Advertising expenditures include product promotion and brand development; both of those activities may lead to intangible assets (Lev and 
Sougiannis 1996). Moreover, improved IT may increase the productivity of advertising activities by more quickly identifying successful and unsuccessful promotion and development programs.

\subsubsection{Hypothesis 2}

H1 predicts that R\&D productivity increases following a first-time CIO appointment. Even if H1 is confirmed, however, the findings would not indicate whether productivity increases are priced by the market. If R\&D productivity enhancements are expected to persist -as would be expected if a competitive advantage were obtained -- the market should value R\&D investments in the post-appointment period at least as much as R\&D investments in the preappointment period. Our second hypothesis predicts that R\&D investments in the postappointment period will be valued at least as much as pre-appointment R\&D investments. Thus, our second set of tests examine whether statistically significant R\&D productivity improvements carry economic significance with respect to stock price effects.

To investigate the market’s perception of R\&D productivity improvements, we use the following regression model:

$$
\begin{aligned}
& \mathrm{BHAR}_{\text {it }}=\alpha+\mathrm{POST}_{\mathrm{it}}+\lambda_{1} * \mathrm{PRE}_{\mathrm{it}} * \mathrm{ROAia}_{\mathrm{it}}+\lambda_{2} * \mathrm{POST}^{*} \mathrm{ROAia}_{\mathrm{it}}+ \\
& +\lambda_{3} * \log \mathrm{VV}_{\mathrm{it}}+\lambda_{4} * \mathrm{CAPEXia}_{\mathrm{it}}+\lambda_{5} * \mathrm{PRE}_{\mathrm{it}} * \mathrm{RDia}_{\mathrm{it}}+\lambda_{6} * \mathrm{POST}_{\mathrm{it}} * \mathrm{RDia}_{\mathrm{it}}+\mathrm{FE}_{\mathrm{t}}+ \\
& \varepsilon_{\text {it }}
\end{aligned}
$$

BHAR $_{\text {it }}$ is the buy and hold abnormal return, found as the buy and hold raw return for firm i over fiscal year $t$ less the return during that same year for firms in the same market capitalization decile. ROAia is industry adjusted return on assets, found as ROA less the median ROA for a firm's industry in the same fiscal year. CAPEXia is industry-adjusted capital expenditures, found as CAPEX less the industry median CAPEX for the corresponding fiscal year. PRE is an indicator variable equal to 1 in the pre-appointment window and 0 otherwise. RDia is industryadjusted R\&D expenditures deflated by sales, found as R\&D expenditures less median industry 
$R \& D$ expenditures for the corresponding fiscal year. We deflate $R \& D$ expenditures by sales because sales are a common benchmark for estimating the intensity of R\&D expenditures. All other variables are previously defined.

We include firms' industry-adjusted return on assets (ROAia) in the model because R\&D productivity improvements are ultimately reflected in ROA. The model compares the association between abnormal stock returns (BHAR) and unexpected return on assets (ROAia) and unexpected R\&D investments (RDia), before and after a CIO is appointed. The intuition underlying the model is that abnormal stock returns should reflect unexpected ROA and unexpected R\&D investments but not normal, or expected, ROA and R\&D investments. If the market assigns a higher valuation multiple to unexpected asset returns and $R \& D$ investments in the post-appointment period than in the pre-appointment period, we have strong evidence that the market perceives post-appointment $R \& D$ investments to be more productive and persistent than pre-appointment $R \& D$ investments. H2 predicts that $\lambda_{2} \geq \lambda_{1}$ and $\lambda_{6} \geq \lambda_{5}$.

In summary, if the market views a new $\mathrm{CIO}$ as securing a competitive advantage for their firm with respect to $R \& D$ investments, the coefficient $\lambda_{6}$ will be positive and significant. A positive coefficient suggests that the market finds R\&D investments to be 'value relevant.' Also, if the market believes that post-appointment $\mathrm{R} \& \mathrm{D}$ investments are more valuable than preappointment $R \& D$ investments, then $\lambda_{6}$ should be larger than $\lambda_{5}$. A large valuation multiple for $\mathrm{R} \& \mathrm{D}$ investments is consistent with a perception that a new CIO appointment secures a sustainable competitive advantage. 


\section{Results}

\subsection{Descriptive Statistics}

Table 1 provides descriptive statistics for our sample based on six years in the sample window ( $\mathrm{t}=-3$ to $\mathrm{t}=+3$ excluding $\mathrm{t}=0$ ). Continuous variables are winsorized at the $1^{\text {st }}$ and $99^{\text {th }}$ percentile. We exclude $t=0$ from descriptive statistics because that year is not used in any regression estimates. As discussed earlier, our sample is based on 118 first-time CIO appointments and each of the 118 firms is represented at least twice in the pre- and twice in the post-appointment periods.

$\mathrm{R} \& \mathrm{D}(\mathrm{RD})$ and advertising (ADV) expenditures as a percentage of average total assets is $4.6 \%$ and $1.3 \%$ on average, respectively, compared to capital expenditures (CAPEX) of 7.1\%. Including only firm-years that reported R\&D expenditures greater than zero, ${ }^{11}$ the average research and development expenditure (capital expenditure) is 8.9\% (5.8\%) of average total assets (not tabulated). Thus, R\&D expenditures and capital expenditures are of similar economic significance. The size-adjusted, buy-and-hold returns (BHAR) are found as annual returns (RETURNS) over a firm's fiscal year minus the industry median buy-and-hold return over the same period. BHAR are a common measure of unexpected or abnormal returns. Similarly, ROAia is a firm's operating return on assets (ROA) minus the median operating return on asset (medROA) over the same fiscal year for all firms in the same industry. We use the Compustat convention for fiscal year.

Table 2 provides bivariate correlation statistics. Caution must be used in interpreting the correlations since they are based on pooled data for both pre- and post-appointment years. ROA is, of course, positively correlated with industry median return on assets (mdROA). ROA is

\footnotetext{
${ }^{11}$ If $\mathrm{RD}$ or $\mathrm{ADV}$ is missing in a firm-year, the missing value is set to zero.
} 
negatively correlated with $R \& D$ spending $(R D)$, which is not surprising because all research and development spending is expensed in the year of the expenditure under U.S. accounting principles. ROA is increasing with firm size (logMV). CAPEX (capital expenditures) is insignificantly correlated with logMV, suggesting that the scaling of capital expenditures by total assets is effective at eliminating size effects.

\subsection{Productivity of Knowledge Assets}

In this paper, we focus, primarily, on whether a new $\mathrm{CIO}$ affects the productivity of a relatively small slice of total assets, i.e., investments in knowledge assets. Table 3 (model 1) provides strong support for $\mathrm{H} 1$ which predicts that the productivity of R\&D investments will improve after the appointment of a new CIO. The negative coefficient on RD (-0.241) is expected due to the mechanical effect of immediate expensing of $R \& D$ expenditures on accounting earnings. As R\&D spending increases, contemporaneous pre-tax earnings and ROA will necessarily decline, absent any productivity effects. ${ }^{12}$ The most critical variable in the model is the interaction term, POST*RD. As predicted by $\mathrm{H} 1$, the coefficient on the interaction term is positive $(+0.387)$ and significant (two-tailed p-value $=0.043) .{ }^{13}$ On average, the coefficient on RD increases from -0.241, before the CIO appointment, to +0.146 after the CIO appointment.

One interpretation of the positive coefficient for RD after appointing a first-time CIO is that payoffs from R\&D spending are realized contemporaneous with expenditures. This interpretation would suggest a very quick payback to R\&D spending. A second interpretation, and one that is more reasonable in our view, is that R\&D spending is relatively "sticky." Under this interpretation, the positive association between ROA and contemporaneous R\&D spending after the CIO appointment reflects (improved) current returns to previous years' investments in

\footnotetext{
${ }^{12}$ If the only effect were a mechanical accounting effect, the coefficient on RD would be equal to -1 . Offsetting productivity effects can explain why the coefficient on RD is greater than -1.0.

${ }^{13}$ All p-values are two-tailed.
} 
$R \& D$. This latter interpretation would also explain why the coefficient on current year R\&D spending prior to the CIO appointment is -0.241 rather than -1.0 , which is the expected value of the coefficient given the pure mechanical effect on pre-tax ROA from spending $\$ 1$ on R\&D. In any event, the productivity of R\&D investments (expenditures) increases significantly following the appointment of a first-time CIO. This is strong evidence that the strategic changes that are implied by creating a new CIO position benefit the firm by increasing the return on $\mathrm{R} \& \mathrm{D}$ investments. While we cannot conclude that integrating CIO positions into the top management team enhances the productivity of physical IT investments, we can conclude that there are spillovers into R\&D productivity.

Table 3 (model 2) repeats the analysis using RDADV (the sum of R\&D and advertising expenditures, scaled by average total assets) in the place of RD. Improved IT management is likely to increase the productivity of advertising activities by more quickly identifying successful and unsuccessful promotion and development programs. The interaction term POST*RDADV is positive and significant ( $\mathrm{p}$-value $=0.048)$, suggesting, again, that the productivity of investments in knowledge-based assets improves following the CIO appointment.

In table 4, we add capital expenditures, CAPEX, and the interaction term, POST*CAPEX, to models 1 and 2 from table 3. Our motivation behind this revised model is to examine whether the association between ROA and R\&D expenditures, before and after the CIO appointment, is the result of firms spending more on $R \& D$ when profitability is relatively strong. If that is the case, we would expect to see a similar association between capital expenditures and ROA. As shown in table 4, the coefficient on CAPEX is positive and significant in both models. This positive coefficient is not surprising because more profitable firms are likely to have a larger set of positive net present value projects than less profitable firms. By contrast, the 
coefficient on the interaction term, POST*CAPEX, is positive but statistically insignificant (pvalues $=0.245$ and 0.313 in models 1 and 2, respectively). We also find that the coefficients on POST*RD and POST*RDADV achieve a higher statistical significance in table 4 (p-values = 0.019 and 0.014 , respectively) than in table 3 (p-values $=0.043$ and 0.048 , respectively). This outcome suggests that CAPEX and POST*CAPEX are correlated omitted variables in table 3.

In table 5, as a robustness test, we used lagged RD and lagged RDADV rather than R\&D and advertising expenditures that are concurrent with the dependent variable, ROA. The models in table 5 test whether the productivity of the preceding year's R\&D investment is improved following the new CIO. The results in table 5 are similar qualitatively and quantitatively to those in table 4 which uses contemporaneous R\&D and advertising expenditures as independent variables. The similarity of the results in tables 4 and 5 are consistent with 'sticky' level of R\&D and advertising over time for a firm.

\subsection{Market's Perception of R\&D Investments}

Table 6 reports findings for our second hypothesis which examines the market's valuation of R\&D investments. H2 predicts that the market will value post-appointment period R\&D investments more than pre-announcement investments. Ideally, we would use measures of the productivity of R\&D in each of our two sample windows by isolating the component of ROA that can be attributed each year to $R \& D$ investments. However, there is no reliable way to measure R\&D productivity at the individual firm level. As an alternative, we compare the market's valuation of ROA and R\&D spending in the pre- and post-appointment periods. If R\&D productivity increases over the two periods and if that productivity increase is perceived by the market as persistent, we would expect the market to value R\&D spending in the postappointment period more than in the pre-announcement period. If the realized productivity, as 
reflected in ROA, is at least as persistent in the post-appointment as the pre-appointment period, we would expect the market to value ROA in the post-appointment period at least as highly as in the pre-appointment period.

Because we examine the market's perception of the sustainability of RD productivity without specifically modeling the productivity component of those expenditures, the coefficients $\lambda_{5}$ for R\&D investments in the pre-announcement period and $\lambda_{6}$ for $R \& D$ investments in the post-announcement period capture the joint effects of the perceived productivity of R\&D expenditures and the market's valuation multiple for that (unknown) productivity coefficient. The valuation multiples for $\mathrm{R} \& \mathrm{D}$ and ROA are increasing functions of the market's perception of the persistence of the productivity coefficient.

Because the productivity of RD expenditures must eventually affect ROA, Table 6 , column (1), compares the pre- and post-appointment valuation of unexpected ROA. We find the coefficient on unexpected ROA is statistically significant in the post-appointment period but not the pre-announcement period. The valuation coefficient for the unexpected ROA in the postannouncement period is positive and significant $(\mathrm{p}$-value $=0.002)$. And, the difference between the pre- and post-appointment coefficients for unexpected ROA is marginally significant (pvalue $=0.087$, untabulated). The evidence suggests that the market views ROA as at least as persistent in the post-appointment period as in the pre-appointment period. We cannot, of course, be certain of what portion of ROA, if any, is related to R\&D productivity. Thus, we are unable to make strong statements about how changes in R\&D productivity contributed to the market's perception of the persistence of ROA in the post-appointment period.

Table 6, column (2), adds unexpected R\&D expenditures, RDia, as an independent variable to the model in column (1). We find that the coefficients for unexpected ROA and 
unexpected R\&D are both statistically significant (p-values $<0.001)$ in the post-appointment period but neither is significant in the pre-appointment period. In other words, the market's valuation of unexpected ROA and R\&D investments is positive but insignificant in the preappointment period ( $\mathrm{p}$-values $\geq 0.280$ ), and positive and significant in the post-appointment period (p-value $<0.001)$.

There is weak evidence that the valuation coefficients for ROA and R\&D both increase post-appointment. In model 2, the difference between the pre- and post-appointment coefficients for unexpected ROA is marginally significant ( $\mathrm{p}$-value $=0.043$, untabulated). However, the difference between coefficients over the two periods for unexpected R\&D fails to reach the conventional level of significance (p-value $=0.139$, untabulated). Thus, while abnormal market returns are more closely associated with unexpected $R \& D$ investments after the new CIO appointment than before, the valuation multiple for R\&D investments is not significantly different when comparing the pre- and post-appointment periods. On balance, our findings support the assertion that new CIO appointments represent strategic changes in IT management that favorably affect firm value. We believe that the low statistical significance for the change in the market's valuation of R\&D investments after the CIO appointment is partially due to the fact that we are unable to isolate the component of ROA that represents the incremental ROA from improved productivity of R\&D activities following the CIO appointment.

\subsection{Conclusions and Avenues for Further Research}

This paper examines whether and how strategic changes to IT management affect firm performance. We find that the productivity of R\&D investments is significantly improved following the appointment of a new CIO. We also find that the market's assessment of the economic value of $\mathrm{R} \& \mathrm{D}$ investments is at least as high after the appointment as before. 
Our findings suggest two broad conclusions. First, to understand the impact of IT investments on firm performance, it is important to consider the role of IT management capability. Second, the impact of IT investments on firm performance may flow from improved productivity of investments which are not directly related to IT.

There are a number of avenues for further research. One possibility would be to devise more reliable measures of the productivity of knowledge-based assets, including measures that capture the long run benefits of current R\&D expenditures at the firm level. Another extension would be to use data about IT investments in models similar to those used in this paper as a way to test for direct changes in the productivity of IT when new CIOs are appointed. Also, given the long-standing nature of the IT productivity paradox, it would be useful to see whether alternative 'slices' of firm performance allow one to identify productivity effects from changes in IT strategy. Finally, it would be interesting to examine whether the likelihood that the appointment of a CIO will achieve a competitive advantage is affected by the quality of the appointed CIO. 


\section{REFERENCES}

Aier, J., J. Comprix, and M. T. Gunlock. "The Financial Expertise of CFOs and Accounting Restatements.” Accounting Horizons, (2005):19 (3):123-135.

Alavi, M., and D. Leidner. "Knowledge Management Systems: Issues, Challenges and Benefits.” Communication of the Association for Information Systems, (1999): 1 (7): 1-28.

Ang, J., B. Lauterbach, and J. Vu. "Efficient Labor and Capital Markets: Evidence from CEO Appointments.” Financial Management, (2003): 32 (2): 27-52.

Armstrong, C. P. and V. Sambamurthy. "Information Technology Assimilation in Firms: The Influence of Senior Leadership and IT Infrastructures.” Information Systems Research, (1999): 10 (4): 304-327.

Artes, J. "Long-run Versus Short-run Decisions: R\&D and Market Structure in Spanish Firms.” Research Policy, (2009): 38(1):120-132.

Artz, K.W., P.M. Norman, and D.E. Hatfield. "Firm Rerformance: a Longitudinal Study of R\&D, Patents, and Product Innovation.” Academy of Management, Best Conference Paper, 2003.

Aral, S and P. Weill. "IT Assets, Organizational Capabilities and Firm Performance: Do Resource Allocations and Organizational Differences Explain Performance Variations?” Working paper. MIT Sloan School of Management, CISR, Cambridge, Massachusetts, 2007.

Autor, D. H., L.F. Katz, and A.B. Krueger. "Computing Enequality: Have Computers Changed the Labor Market?” The Quarterly Journal of Economics, (1998): 113 (4): 1169-1213.

Barua, A., C.H. Kriebel, and T. Mukhopadhyay. "Information Technologies and Business Value: An Analytic and Empirical Investigation.” Information Systems Research, (1995): 6 (1): 3-22.

Barua, A., C.H. Kriebel, and T. Mukhopadhyay. "An Economic Analysis of Strategic Information Technology Investments.” MIS Quarterly, (2008): 15 (3): 313-331.

Berson, Y., and J.D. Linton. “An Examination of the Relationships between Leadership Style, Quality, and Employee Satisfaction in R\&D Versus Administrative Environments.” $R \& D$ Management, (2005): 35 (1): 51-60.

Bone, S. and T. Saxon. “Developing Effective Technology Strategies.” Research Technology Management, (2009): 43 (4) 50-59.

Bowman, E. and D. Hurry. "Strategy Through the Option Lens: An Integrated View of Resource Investments and the Incremental-choice Process." Academy of Management Review, (1993): 18 (4): 760-782.

Bharadwaj, A. S. "A Resource-based Perspective on Information Technology Capability and Firm Performance: an Empirical Investigation.” MIS Quarterly, (2000): 24 (1): 169-196.

Bhatt, G. and V. Grover. "Types of Information Technology Capabilities and their Role in Competitive Advantage: An Empirical Study.” Journal of Management Information Systems, (2005): 22 (2): 253-277.

Bhojraj, S., C.M. Lee, and D. Oler. "What's My Line? A Comparison of Industry Classification Schemes for Capital Market Research.” Journal of Accounting Research, (2003): 41 (5): 745-774.

Bone. S. and T. Saxon. “Developing Effective Technology Strategies.” Research Technology Management, (2000): 43(4): 50-58. 
Broadbent, M., P. Weill, and D. Clair. "The Implications of Information Technology Infrastructure for Business Process Redesign.” MIS Quarterly, (1999): 23 (2):159-182

Brynjolfsson, E., and S. Yang. "The Intangible Benefits and Costs of Investments: Evidence from Financial Markets." Proceedings of the Eighteenth International Conference on Information Systems, (1997): Atlanta, GA, 147-166.

Carr, N. G. “IT Doesn’t Matter.” Harvard Business Review, (2003): 81 (5): 41-49.

Caves, R., and P. Ghemawat. “Identifying Mobility Barriers.”_Strategic Management Journal, (1992): 13 (1): 1-12

Chatterjee, D., V.J. Richardson, and R.W. Zmud. "Examining the Shareholder Wealth Effects of Announcements of Newly Created CIO Positions.” MIS Quarterly, (2001): 25 (1): 43 -70.

Chen, S., M. L. Defond and C. W. Park. "Voluntary Disclosure of Balance Sheet Information in Quarterly Earnings Announcements.” Journal of Accounting and Economics, (2001): 33 (2): 229-251.

Chan, L., J. Lakonishok, and T. Sougiannis. “The Stock Market Valuation of Research and Development Expenditures.” Journal of Finance, (2001): 56, 2431-2456.

Davidson, W.N., B. Xie, and W. Xu. "Market Reaction to Voluntary Announcements of Audit Committee Appointments: The Effect of Financial Expertise.” Journal of Accounting and Public Policy, (2004): 23 (4): 279-293.

Dedrick, J., V. Gurbaxani, and K. Kraemer. "Information Technology and Economic Performance: A Critical Review of the Empirical Evidence.” ACM Computing Surveys, (2003): 35 (1): 1-28.

DeFond, M., R.N. Hann, and X. Hu. "Does the Market Value Financial Expertise on Audit Committees of Board of Directors?” Journal of Accounting Research, (2005): 43 (2): 153193.

DeFond, M.., Y. Konchitchki, J. Mcmullin and D. O’Leary. “To Know or Not to Know: Stock Market Implications of Firms with Superior Knowledge Management.” SSRN, Working paper, 2009.

Dehning, B., V.J. Richardson, and R.W. Zmud. “The Value Relevance of Announcements of Transformational Information Technology Investments.” MIS Quarterly, (2003): 27 (4): 637-656.

Dehning, B., and T. Stratopoulos. "DuPont Analysis of an IT-enabled Competitive Advantage.” International Journal of Accounting Information Systems, (2002): 3 (3):165-176

Earl, M. “Knowledge Management Strategies: Toward Taxonomy.” Journal of Management Information Systems, (2001): 18 (1): 215-233.

Eberhart, A.C., W.F. Maxwell, and A.R. Siddique. "An Examination of Long-term Excess Stock Returns and Operating Performance Following R\&D Increases.” Journal of Finance, (2004): 59 (2): 623-651.

Feeny, D. F., B.R. Edwards, and K.M. Simpson. "Understanding the CEO/CIO Relationship.” MIS Quarterly, (1992): 16 (4): 435-447.

Guan, L., S.G. Sutton, C.J. Chang, and V. Arnold. "Further Evidence on Shareholder Wealth Effects of Announcements for Newly Created CIO Positions." Database for Advances in Information Systems, (2006): 37 (2\&3): 176-187.

Hallikianen, P., H. Kivijarvi, and K. Nurmimaki. "Evaluating Strategic IT Investments: An Assessment of Investment Alternatives for a Web Content Management System." Proceedings of the 35 ${ }^{\text {th }}$ International Conference on System Science, 2002. 
Johnson, J. “A Consequential Approach to Accounting for R\&D.” Journal of Accounting Research, (1967): Autumn: 164-72.

Khallaf, A., and T. Skantz. "The Effects of Information Technology Expertise on the Market Value of a Firm.” Journal of Information Systems, (2007): 21(1): 83-105.

Khallaf, A. and T. Skantz. "Does Long-Term Performance Improve Following the Appointment of a CIO?” International Journal of Accounting Information Systems, (2010): 12 (1): 57-78

Kettinger, W., V. Grover, S. Guhan, and A. Segars. "Strategic Information Systems Revisited: A Study in Sustainability and Performance.” MIS Quarterly, (1994): 18 (1): 31-58.

Kobelsky. K., V. Richardson, R. Smith, and R. Zmud. "Determinants and Consequences of Firm Information Technology Budgets.” The Accounting Review, (2008): 83 (4): 957-995.

Lev, B. and T. Sougiannis. "The Capitalization, Amortization and Value Relevance of R\&D." Journal of Accounting and Economics, (1996): 21:107-138.

Lev, B., S. Radhakrishnan, and M. Ciftci. “The Stock Market Valuation of R\&D Leaders.” SSRN, Working paper, 2006.

Machlup, F. “The Production and Distribution of Knowledge in the United States.” Princeton: Princeton University Press, 1962.

Malerba, F. "Learning by Firms and Incremental Technical Change.” Economic Journal, (1992): 102 (413): 845-859.

Medcof, J. W. “The Organizational Strategy Influence of the Chief Technology Officer.” $R \& D$ Management, (2008): 38 (4): 406-419.

Nonaka, I. “The Knowledge Creating Company.” Harvard Business Review, (1991): 69 (NovDec): 96-104.

Oh, W. J., W. Kim, and V.J. Richardson. "The Moderating Effects of Context on the Market Reaction to IT Investments.” Journal of Information Systems, (2006): 20 (1):19-44.

Uttal. B., A. Kantrow, L.H. Linden, and S. Stocks. "Building R\&D Leadership and Creditability.” Research Technology Management, (1992): 35(3): 15-24.

Roberts, E. B., and P.R. Bellotti. "Managerial Determinants of Industrial R\&D Performance: An Analysis of the Global Chemicals/Materials Industry.” Technological Forecasting \& Social Change, (2002): 69: 129-152.

Santhanam, R., and E. Hartono. "Issues in Linking Information Technology Capability to Firm Performance.” MIS Quarterly, (2003): 27 (1): 125-153.

Shevlin, T. “The Valuation of R\&D Firms with R\&D Limited Partnerships.” The Accounting Review, (1991): 66 (1): 1-21.

Shin, N. “The Impact of Information Technology on Coordination Costs: Implications for Firm Productivity.” Proceedings of the Eighteenth International Conference on Information Systems, 1997.

Sougiannis, T. "The Accounting-based Valuations of Corporate R\&D.” The Accounting Review, (1994): 69 (1): 44-68.

Tanriverdi, H. "Information Technology Relatedness, Knowledge Management Capability and Performance of Multibusiness Firms.” MIS Quarterly, (2005): 29 (2): 311-334.

Tsang, E. W. K., P.S.L. Yip, and M.H. Toh. "The Impact of R\&D on Value Added for Domestic and Foreign Firms in a Newly Industrialized Economy.” International Business Review, (2008): 17 (4): 423-441.

Wade, M. and J. Hulland. "The Resource-based View and Information Systems Research: Review, Extension, and Suggestions for Future Research. MIS Quarterly, (2004): 28 (1): 107-142. 
Weill, P. and S. Aral. “Generating Premium Return on IT Investments.” MIT Sloan Management Review, (2006): 47 (2): 39-48.

Weill, P. and S. Aral.” IT Savvy Pays Off: How Top Performers Match IT Portfolios and Organizational Practices.” Working paper, MIT Sloan School of Management, CISR, Cambridge, Massachusetts, 2005.

Weill, P. and J.W. Ross. "IT Governance: How Top Performers Manage IT Decision Rights for Superior Results.” Boston, Harvard Business School Press, 2004.

Yayla, A. and Q. Hu. "Determinants of CIO Compensation Structure and Its Impact on Firm Performance.” Proceedings of the 41st Annual Hawaii International Conference on System Sciences, 2008. 
Figure 1: Theoretical Model of $R \& D$ productivity

IT investments

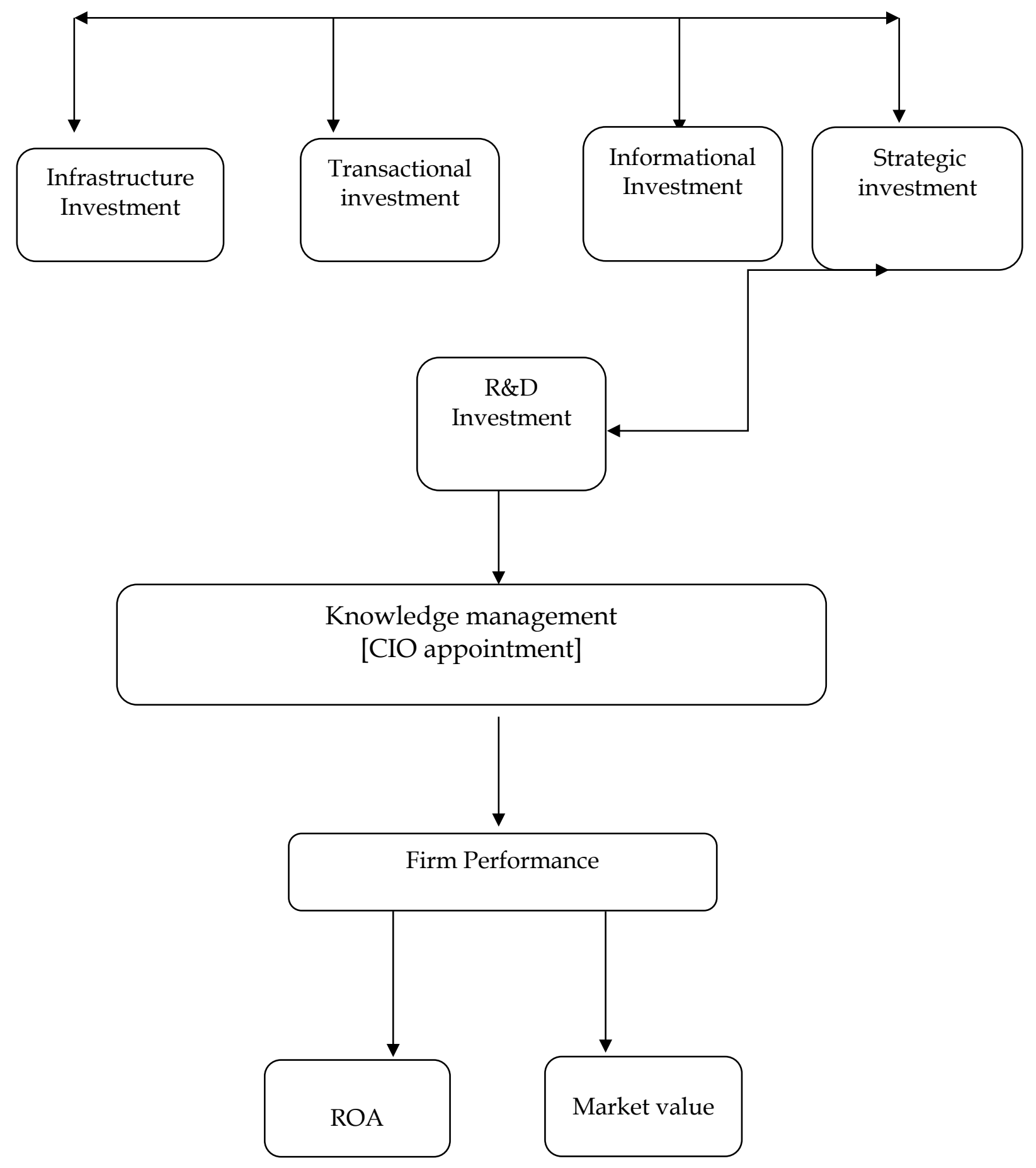


Table 1

Sample descriptive statistics

\begin{tabular}{lcrrrr}
\hline Variable & N & Mean & Median & Min & Max \\
\hline RETURN & 680 & 0.181 & 0.073 & -0.903 & 3.888 \\
BHAR & 659 & 0.059 & -0.037 & -0.995 & 3.577 \\
ROA & 679 & 0.121 & 0.118 & -0.867 & 0.479 \\
mdROA & 680 & 0.081 & 0.104 & -0.355 & 0.206 \\
ROAia & 679 & 0.041 & 0.023 & -0.873 & 0.442 \\
logMV & 680 & 7.11 & 6.81 & 1.508 & 11.487 \\
RD & 680 & 0.046 & 0.003 & 0 & 0.506 \\
ADV & 680 & 0.013 & 0 & 0 & 0.267 \\
RDADV & 680 & 0.059 & 0.019 & 0 & 0.506 \\
CAPEX & 645 & 0.071 & 0.051 & 0 & 0.427 \\
POST & 680 & 0.494 & 0 & 0 & 1.000 \\
\hline
\end{tabular}

BHAR is the buy and hold abnormal return, found as the buy and hold raw stock return (RETURN) for firm i over fiscal year $t$ less the value-weighted stock return during that same year for all firms in the same market-value size-decile as firm i. Stock return data is from CRSP. All other variables are from COMPUSTAT (in bold font). ROA is firm performance measured by operating return on assets, found as income before interest, taxes, and depreciation (Compustat item, OIBDP) divided by average total assets (AT). mdROA is the industry median ROA. POST $=1$ for fiscal years $t=+1$, +2 , and +3 following the CIO appointment, and 0 for years $t=-3$, -2 , and -1 prior to the appointment, where $\mathrm{t}=0$ is the appointment year. $\mathrm{RD}$ is the ratio of a firm's research and development expenditure (XRD) to average total assets. ADV is the ratio of a firm's advertising expenditure (XAD) to average total assets. RDADV is the ratio of the sum of a firm's research and development (XRD) plus advertising expenditures (XAD) to average total assets. CAPEX is capital expenditures (CAPX) scaled by average total assets. logMV is the natural log of firm market value, where market value is measured as a fiscal year-end stock price (PRCC_F) multiplied by the number of common shares outstanding (CSHO) at fiscal year-end. 
Table 2

Pearson correlation statistics

(Correlation coefficient, p-value, and sample size are reported in each cell)

\begin{tabular}{|c|c|c|c|c|c|c|c|c|c|}
\hline & (1) & (2) & (3) & (4) & (5) & (6) & (7) & (8) & (9) \\
\hline 1. RETURN & $\begin{array}{r}1.00000 \\
680\end{array}$ & $\begin{array}{r}0.95666 \\
<.0001 \\
659\end{array}$ & $\begin{array}{r}0.13288 \\
0.0005 \\
679\end{array}$ & $\begin{array}{r}-0.05266 \\
0.1702 \\
680\end{array}$ & $\begin{array}{r}0.16856 \\
<.0001 \\
679\end{array}$ & $\begin{array}{r}0.14217 \\
0.0002 \\
680\end{array}$ & $\begin{array}{r}0.11403 \\
0.0029 \\
680\end{array}$ & $\begin{array}{r}0.12272 \\
0.0013 \\
680\end{array}$ & $\begin{array}{r}0.04955 \\
0.2088 \\
645\end{array}$ \\
\hline 2. BHAR & & $\begin{array}{r}1.00000 \\
659\end{array}$ & $\begin{array}{r}0.11229 \\
0.0039 \\
658\end{array}$ & $\begin{array}{r}-0.08251 \\
0.0342 \\
659\end{array}$ & $\begin{array}{r}0.16577 \\
<.0001 \\
658\end{array}$ & $\begin{array}{r}0.14286 \\
0.0002 \\
659\end{array}$ & $\begin{array}{r}0.11717 \\
0.0026 \\
659\end{array}$ & $\begin{array}{r}0.12006 \\
0.0020 \\
659\end{array}$ & $\begin{array}{r}0.04861 \\
0.2249 \\
625\end{array}$ \\
\hline 3. ROA & & & $\begin{array}{r}1.00000 \\
679\end{array}$ & $\begin{array}{r}0.32674 \\
<.0001 \\
679\end{array}$ & $\begin{array}{r}0.81535 \\
<.0001 \\
679\end{array}$ & $\begin{array}{r}0.25500 \\
<.0001 \\
679\end{array}$ & $\begin{array}{r}-0.12288 \\
0.0013 \\
679\end{array}$ & $\begin{array}{r}-0.01577 \\
0.6817 \\
679\end{array}$ & $\begin{array}{r}0.27687 \\
<.0001 \\
644\end{array}$ \\
\hline 4. mdROA & & & & $\begin{array}{r}1.00000 \\
680\end{array}$ & $\begin{array}{r}-0.27574 \\
<.0001 \\
679\end{array}$ & $\begin{array}{r}0.13535 \\
0.0004 \\
680\end{array}$ & $\begin{array}{r}-0.23237 \\
<.0001 \\
680\end{array}$ & $\begin{array}{r}-0.16030 \\
<.0001 \\
680\end{array}$ & $\begin{array}{r}0.16495 \\
<.0001 \\
645\end{array}$ \\
\hline 5. ROAia & & & & & $\begin{array}{r}1.00000 \\
679\end{array}$ & $\begin{array}{r}0.17047 \\
<.0001 \\
679\end{array}$ & $\begin{array}{r}0.01323 \\
0.7307 \\
679\end{array}$ & $\begin{array}{r}0.07962 \\
0.0381 \\
679\end{array}$ & $\begin{array}{r}0.19631 \\
<.0001 \\
644\end{array}$ \\
\hline 6. $\log \mathrm{MV}$ & & & & & & $\begin{array}{r}1.00000 \\
680\end{array}$ & $\begin{array}{r}-0.11370 \\
0.0030 \\
680\end{array}$ & $\begin{array}{r}-0.04183 \\
0.2760 \\
680\end{array}$ & $\begin{array}{r}-0.04218 \\
0.2848 \\
645\end{array}$ \\
\hline 7. RD & & & & & & & $\begin{array}{r}1.00000 \\
680\end{array}$ & $\begin{array}{r}0.93040 \\
<.0001 \\
680\end{array}$ & $\begin{array}{r}-0.06847 \\
0.0823 \\
645\end{array}$ \\
\hline 8. RDADV & & & & & & & & $\begin{array}{r}1.00000 \\
680\end{array}$ & $\begin{array}{r}-0.02805 \\
0.4769 \\
645\end{array}$ \\
\hline 9. CAPEX & & & & & & & & & 1.00000 \\
\hline
\end{tabular}


Table 3

R\&D productivity following CIO appointments as reflected in return on assets (ROA). We use R\&D expenditures as a proxy for $R \& D$ investment in model 1 and the sum of R\&D and advertising expenditures as a proxy for R\&D investment in model 2.

\begin{tabular}{lrr}
\hline Dependent variable: ROA & Coefficient estimate (t-statistic) \\
Independents Variables & Model 1 & Model 2 \\
\hline Intercept & -0.0037 & -0.009 \\
mdROA & $(-0.09)$ & $(-0.20)$ \\
& 0.413 & 0.436 \\
logMV & $* * *(3.81)$ & $* * *(3.88)$ \\
& 0.012 & 0.012 \\
POST & $* *(2.20)$ & $* *(2.28)$ \\
& 0.008 & 0.006 \\
RD & $(0.81)$ & $(0.59)$ \\
& -0.241 & \\
POST*RD & $(-1.38)$ & \\
RDADV & 0.387 & \\
POST*RDADV & $* *(2.04)$ & \\
R-squared & & -0.124 \\
N & & $(-0.79)$ \\
Year fixed effects & & 0.339 \\
\hline
\end{tabular}

Significant at two-tailed p-value: ${ }^{*} 0.10,{ }^{* *} 0.05, * * * 0.01$

All variables are from COMPUSTAT (in bold font). ROA is firm performance measured by operating return on assets, found as income before interest, taxes, and depreciation (Compustat item, OIBDP) divided by average total assets (AT). mdROA is the industry median ROA over a firm's fiscal year. $\log M V$ is the natural log of a firm's market value, where market value is measured as a firm's fiscal year-end stock price (PRCC_F) multiplied by the number of common shares outstanding (CSHO) at fiscal year-end. POST $=1$ for fiscal years $t=+1,+2$, and +3 following the CIO appointment, and 0 for years $t=-3,-2$, and -1 prior to the appointment, where $t=0$ is the appointment year. RD is the ratio of a firm's research and development expenditure (XRD) to average total assets. ADV is the ratio of a firm's advertising expenditure (XAD) to average total assets. RDADV is the ratio of the sum of a firm's research and development (XRD) plus advertising expenditures (XAD) to average total assets. 
Table 4

R\&D productivity following CIO appointments as reflected in return on assets (ROA). We use R\&D expenditures as a proxy for R\&D investment in model 1 and the sum of $R \& D$ and advertising expenditures as a proxy for R\&D investment in model 2. Both models control for capital expenditures.

\begin{tabular}{|c|c|c|}
\hline \multirow{2}{*}{$\begin{array}{l}\text { Dependent variable: ROA } \\
\text { Independents Variables }\end{array}$} & \multicolumn{2}{|c|}{ Coefficient estimate (t-statistic) } \\
\hline & Model 1 & Model 2 \\
\hline \multirow[t]{2}{*}{ Intercept } & -0.023 & -0.028 \\
\hline & $(-0.52)$ & $(-0.65)$ \\
\hline \multirow[t]{2}{*}{ mdROA } & 0.290 & 0.312 \\
\hline & $* * *(2.81)$ & $* * *(2.96)$ \\
\hline \multirow[t]{2}{*}{$\log M V$} & 0.0149 & 0.015 \\
\hline & $* * *(2.83)$ & $* * *(2.90)$ \\
\hline \multirow[t]{2}{*}{ POST } & -0.010 & -0.010 \\
\hline & $(-0.60)$ & $(-0.61)$ \\
\hline \multirow[t]{2}{*}{ CAPEX } & 0.421 & 0.438 \\
\hline & $* *(1.94)$ & $* *(1.98)$ \\
\hline \multirow[t]{2}{*}{$\mathrm{RD}$} & -0.282 & \\
\hline & $(-1.63)$ & \\
\hline \multirow[t]{2}{*}{ RDADV } & & -0.178 \\
\hline & & $(-1.14)$ \\
\hline \multirow[t]{2}{*}{ POST*CAPEX } & 0.193 & 0.168 \\
\hline & $(1.17)$ & $(1.01)$ \\
\hline \multirow[t]{2}{*}{$\mathrm{POST}^{*} \mathrm{RD}$} & 0.461 & \\
\hline & $* *(2.48)$ & \\
\hline \multirow[t]{2}{*}{ POST*RDADV } & & 0.399 \\
\hline & & $* *(2.38)$ \\
\hline R-squared & 0.264 & 0.259 \\
\hline $\mathrm{N}$ & 644 & 644 \\
\hline Year fixed effects & yes & yes \\
\hline
\end{tabular}

Significant at two-tailed p-value: *0.10, **0.05, ***0.01

All variables are from COMPUSTAT (in bold font). ROA is firm performance measured by operating return on assets, found as income before interest, taxes, and depreciation (Compustat item, OIBDP) divided by average total assets (AT). mdROA is the industry median ROA over a firm's fiscal year. logMV is the natural log of a firm's market value, where market value is measured as a firm's fiscal year-end stock price (PRCC_F) multiplied by the number of common shares outstanding (CSHO) at fiscal year-end. POST $=1$ for fiscal years $t=+1$, +2 , and +3 following the CIO appointment, and 0 for years $t=-3$, -2 , and -1 prior to the appointment, where $t=0$ is the appointment year. CAPEX is capital expenditures (CAPX) scaled by average total assets. RD is the ratio of a firm's research and development expenditure (XRD) to average total assets. ADV is the ratio of a firm's advertising 
expenditure (XAD) to average total assets. RDADV is the ratio of the sum of a firm's research and development (XRD) plus advertising expenditures (XAD) to average total assets.

Table 5

R\&D productivity following CIO appointments as reflected in return on assets (ROA), using lagged (by one year) R\&D expenditures as a proxy for R\&D investment in model 1, and the sum of lagged R\&D and lagged advertising expenditures as a proxy for R\&D investment in model 2. Both models control for capital expenditures.

\begin{tabular}{|c|c|c|}
\hline \multirow{2}{*}{$\begin{array}{l}\text { Dependent variable: ROA } \\
\text { Independent variables }\end{array}$} & \multicolumn{2}{|c|}{ Coefficient estimate (t-statistic) } \\
\hline & Model 1 & Model 2 \\
\hline \multirow[t]{2}{*}{ Intercept } & -0.022 & -0.029 \\
\hline & $(-0.49)$ & $(-0.66)$ \\
\hline \multirow[t]{2}{*}{ mdROA } & 0.289 & 0.312 \\
\hline & $* * *(2.83)$ & $* * *(2.96)$ \\
\hline \multirow[t]{2}{*}{$\log M V$} & 0.015 & 0.015 \\
\hline & $* * *(2.80)$ & $* * *(2.88)$ \\
\hline \multirow[t]{2}{*}{ POST } & -0.009 & -0.009 \\
\hline & $(-0.58)$ & $(-0.55)$ \\
\hline \multirow[t]{2}{*}{ CAPEX } & 0.412 & 0.430 \\
\hline & $*(1.90)$ & $* *(1.96)$ \\
\hline \multirow[t]{2}{*}{ RD (lagged) } & -0.274 & \\
\hline & $(-1.66)$ & \\
\hline \multirow[t]{2}{*}{ RDADV (lagged) } & & -0.161 \\
\hline & & $(-1.11)$ \\
\hline \multirow[t]{2}{*}{ POST*CAPEX } & 0.202 & 0.178 \\
\hline & $(1.24)$ & $(1.08)$ \\
\hline \multirow[t]{2}{*}{ POST*RD (lagged) } & 0.436 & \\
\hline & $* *(2.35)$ & \\
\hline \multirow[t]{2}{*}{ POST*RDADV (lagged) } & & 0.364 \\
\hline & & $* *(2.26)$ \\
\hline R-squared & 0.263 & 0.258 \\
\hline $\mathrm{N}$ & 644 & 644 \\
\hline Year fixed effects & yes & yes \\
\hline
\end{tabular}

Significant at two-tailed p-value: ${ }^{*} 0.10, * * 0.05, * * * 0.01$

All variables are from COMPUSTAT (in bold font). ROA is firm performance measured by operating return on assets, found as income before interest, taxes, and depreciation (Compustat item, OIBDP) divided by average total assets (AT). mdROA is the industry median ROA. $\log M V$ is the natural log of firm market value, where market value is measured as a fiscal year-end stock price (PRCC_F) multiplied by the number of common shares 
outstanding (CSHO) at fiscal year-end. POST $=1$ for fiscal years $t=+1,+2$, and +3 following the CIO appointment, and 0 for years $t=-3,-2$, and -1 prior to the appointment, where $t=0$ is the appointment year. CAPEX is capital expenditures (CAPX) scaled by average total assets. RD is the ratio of a firm's research and development expenditure (XRD) to average total assets. ADV is the ratio of a firm's advertising expenditure (XAD) to average total assets. RDADV is the ratio of the sum of a firm's research and development (XRD) plus advertising expenditures (XAD) to average total assets.

\section{Table 6}

The market's perception of the sustainability of ROA and the productivity of R\&D following CIO appointments

\begin{tabular}{|c|c|c|}
\hline \multirow{2}{*}{$\begin{array}{l}\text { Dependent variable: BHAR } \\
\text { Independents Variables }\end{array}$} & \multicolumn{2}{|c|}{ Coefficient estimate (t-statistic) } \\
\hline & $\begin{array}{r}\text { (1) market valuation } \\
\text { of ROA }\end{array}$ & $\begin{array}{l}\text { (2) market valuation } \\
\text { of ROA and R\&D }\end{array}$ \\
\hline \multirow[t]{2}{*}{ Intercept } & -0.250 & -0.225 \\
\hline & $* *(-2.18)$ & $* *(-2.09)$ \\
\hline \multirow[t]{2}{*}{ POST } & -0.108 & -0.111 \\
\hline & $*(-1.73)$ & $*(-1.80)$ \\
\hline \multirow[t]{2}{*}{$\log M V$} & 0.036 & 0.033 \\
\hline & $* * *(3.22)$ & $* * *(2.99)$ \\
\hline \multirow[t]{2}{*}{ CAPEXia } & 0.444 & 0.440 \\
\hline & $(0.58)$ & $(.75)$ \\
\hline \multirow[t]{2}{*}{ PRE*ROAia } & 0.284 & 0.381 \\
\hline & $(0.25)$ & $(1.07)$ \\
\hline \multirow[t]{2}{*}{ POST*ROAia } & 1.168 & 1.289 \\
\hline & $* * *(3.25)$ & $* * *(3.71)$ \\
\hline \multirow[t]{2}{*}{ PRE*RDia } & & 0.236 \\
\hline & & $(0.95)$ \\
\hline \multirow[t]{2}{*}{ POST*RDia } & & 0.706 \\
\hline & & $* * *(4.77)$ \\
\hline R-squared & 0.087 & 0.099 \\
\hline $\mathrm{N}$ & 624 & 624 \\
\hline Year fixed effects & yes & yes \\
\hline
\end{tabular}

Significant at two-tailed p-value: $* 0.10,{ }^{* *} 0.05, * * * 0.01$

BHAR is the buy and hold abnormal return for firm $i$, found as the buy and hold raw return for firm i over its fiscal year t less the value-weighted buy-and-hold stock return for firms in the same size decile as firm i over the same time period. All return data are from CRSP. All other variables are from COMPUSTAT (in bold font). ROA is firm performance measured by operating return on assets, found as income before interest, taxes, and depreciation (Compustat item, OIBDP) divided by average total assets (AT). ROAia is the industry-adjusted return on assets, found a firm i's ROA less the industry median ROA for the corresponding fiscal year. logMV is the natural log of firm market value, where market value is measured as a fiscal year-end stock price (PRCC_F) multiplied by the 
number of common shares outstanding (CSHO) at fiscal year-end. POST $=1$ for fiscal years $t=+1,+2$, and +3 following the CIO appointment, and 0 for years $t=-3,-2$, and -1 prior to the appointment, where $t=0$ is the appointment year. CAPEXia is CAPEX, as defined earlier, less industry median CAPEX for the corresponding fiscal year. RDia is the industry-adjusted research and development expenditure found as a firm's R\&D expenditures (XRD) scaled by the firm's sales (SALE) less the corresponding fiscal year's industry median R\&D expenditures scaled by sales. 